\title{
Synthesis of a Side-Chain-Tethered Solid Support for Peptide Synthesis
}

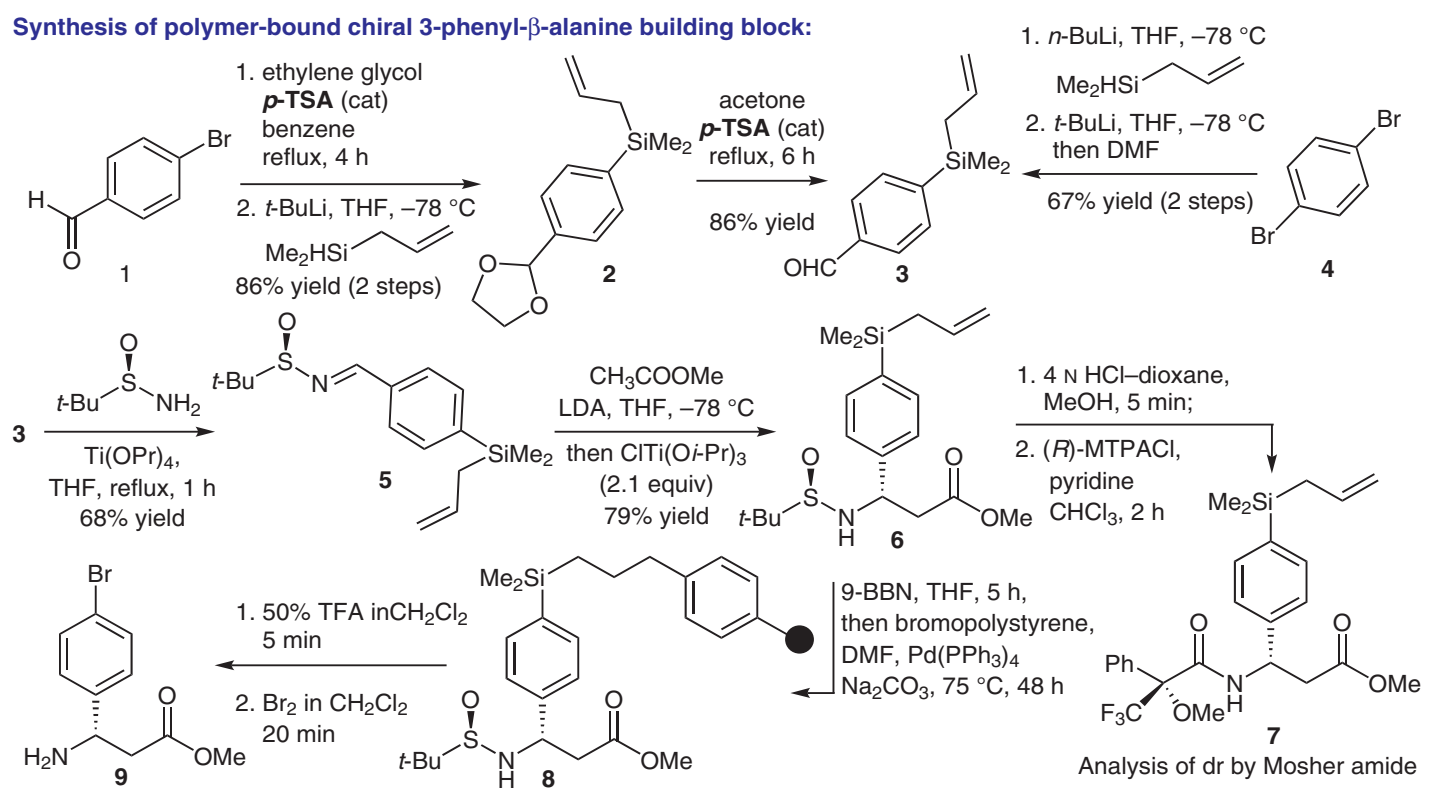

Synthesis of tripeptides from polymer-bound $\beta$-alanine building block:

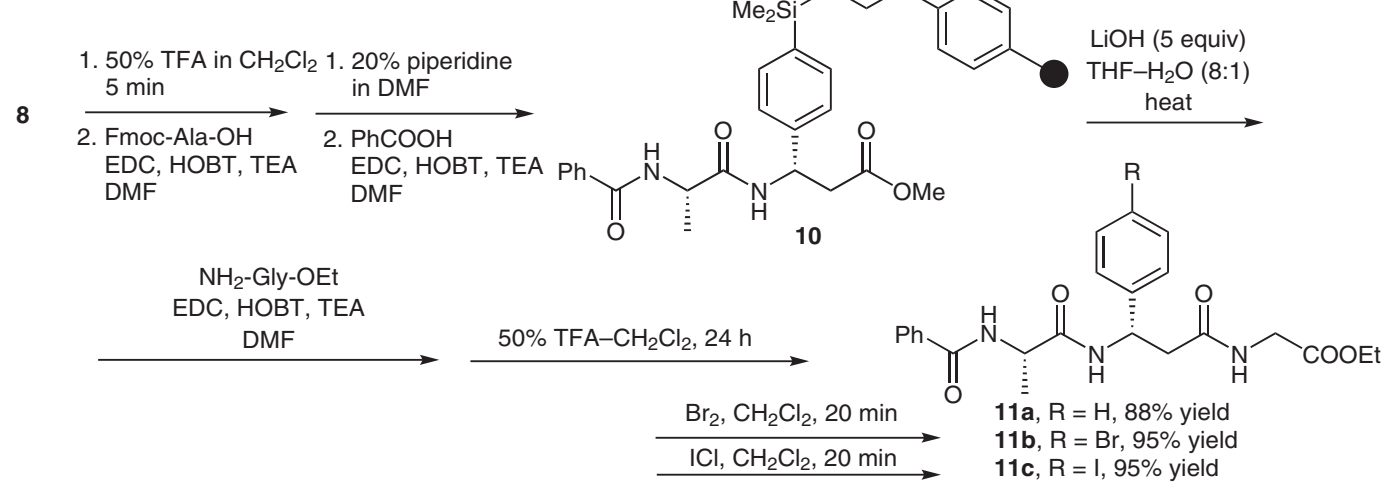

Significance: Silicon-linked solid supports play a major role in peptide syntheses because of the ease with which silicon-based linkers can be attached and detached. In 2000, Lee and Silverman developed silicon-linked side-chain-tethered $\beta$-amino acid building blocks for peptide synthesis.
Comment: The silicon-linked side-chain-tethered $\beta$-amino acid building blocks were synthesized in good yields. The synthesized support permits the elongation of a peptide chain at both its $C$-terminal and $\mathrm{N}$-terminal directions. Furthermore, it can be used for the synthesis of 3 -aryl- $\beta$-alanine-containing tripeptides in good yields.

\section{Key words}

solid-phase peptide synthesis

silicon-linked solid support

$\beta$-amino acids

\section{Syníact}

